\title{
Friedrich Nietzsche \& Alberto Caeiro: paganismo e linguagem
}

\author{
Cláudia Franco Souza*
}

\begin{abstract}
Resumo: Neste artigo pretendemos aproximar reflexões sobre a linguagem apresentadas pelo filósofo Friedrich Nietzsche em seu texto Sobre verdade e mentira no sentido extramoral, e a filosofia pagã do heterônimo de Fernando Pessoa, Alberto Caeiro. Utilizaremos no corpus desta análise o texto de Nietzsche já citado, a obra $O$ Guardador de Rebanhos de autoria de Caeiro, e alguns textos em prosa de Fernando Pessoa, António Mora, Ricardo Reis e Álvaro de Campos. O artigo está dividido em três partes: na primeira, mostraremos as leituras que Pessoa realizou sobre a obra de Nietzsche, no segundo momento mostraremos a dinâmica de linguagem que envolve a filosofia pagã de Alberto Caeiro e suas possíveis relações com a crítica realizada pelo jovem Nietzsche sobre a linguagem e no terceiro momento a relação entre o paganismo de Nietzsche e do mestre Caeiro à luz dos escritos de António Mora, Fernando Pessoa e Ricardo Reis.

Palavras-chave: Nietzsche - linguagem - Alberto Caeiro - Fernando Pessoa - paganismo
\end{abstract}

O paganismo de Nietzsche é um paganismo de estrangeiro.

Há erros constantes de pronúncia na sua interpretação do helenismo ${ }^{1 .}$

Fernando Pessoa

\section{I - Pessoa e Nietzsche: vestígios no espólio}

\footnotetext{
* Pós-doutoranda no Departamento de Filosofia da Universidade de São Paulo, São Paulo, Brasil. E-mail: claudiasouzzza@hotmail.com.

1 PESSOA, 1968, 135.
} 
Souza, C. F.

Nietzsche, com sua filosofia desafiadora e com seu estilo persuasivo, influenciou não somente uma série de outros filósofos (como os franceses Foucault e Deleuze), como também sua escrita foi lida e assimilada no campo literário (prova disso é a influência confessa do filósofo alemão na obra de Thomas Mann, tomando aqui apenas um exemplo).

Fernando Pessoa leu Nietzsche e em seu espaço literário aproveitou aspectos da filosofia nietzschiana para elaborar alguns textos assinados pelo próprio Pessoa e também pelos seus outros eus, como é o caso de António Mora ${ }^{2}$, outro eu pessoano que deixou diversos textos em prosa, alguns dos quais com teor nietzschiano evidente.

As comprovações da leitura que Pessoa realizou da obra de Nietzsche e os resquícios deixados em seu espólio que mostram o reaproveitamento dessas leituras podem ser encontradas em Fernando Pessoa e Nietzsche: o pensamento da pluralidade ${ }^{3}$, livro do pesquisador português Nuno Ribeiro. Um dos documentos publicados nesse livro e que destacamos aqui é uma lista de leitura de Pessoa em que consta o nome de Nietzsche:

Eucken: (um livro característico).

Max Stirner: "O Unico e sua Propriedade."

Max Nordau: "Degenerescencia".

Jules de Gaultier: (um livro Typico).

T. H. Green: (um livro) (?).

Fr. Nietzsche: (livros).

Maurice Barrès: "Um homem livre". (ou outro).

Ibsen: "Theatre" (todo ou parte).

J. Galsworthy: "Theatro" (todo ou parte).

Oscar Wilde: "Theatro em prosa"”.

2 RICCARDI, Mattia. Dionysus or Apollo? The Heteronym António Mora as Moment of Nietzsche’s Reception by Pessoa. Portuguese Studies. v.23, nº1, 2007. p 109-123.

3 PESSOA, 2011.

4 [BNP/E3-48B-62] PESSOA, 2011, 63. Respeitamos na transcrição deste documento a

246 | Cad. Nietzsche, São Paulo, v.36 n.1, p. 245-265, 2015. 
É importante ressaltar sobre esse documento do espólio pessoano a presença do livro Degenerescência de Marx Nordau ${ }^{5}$, pois, como o pesquisador Nuno Ribeiro ressalta em seu livro, a leitura da obra de Nietzsche foi realizada por Fernando Pessoa sobretudo de forma indireta, ou seja, a partir de bibliografia secundária sobre o pensamento de Nietzsche. Em alguns escritos deixados por Pessoa é reproduzida a análise que Nordau realiza de Nietzsche como um degenerado. Outro aspecto importante dessa lista é o nome de Max Stirner, cuja filosofia esboçada em seu livro, O único e sua propriedade, encontra ecos na filosofia nietzschiana.

Há um importante texto no espólio pessoano intitulado Friedrich Nietzsche, transcrito no livro Fernando Pessoa e Nietzsche: o pensamento da pluralidade, em que fica evidente a influência que a leitura de Nordau exerceu sobre a recepção do pensamento nietzschiano realizado por Pessoa:

\section{Friedrich Nietzsche}

1 .

O próprio Nietzsche asseverou que uma filosofia não é senão a expressão de um temperamento. Que não assim suficientemente. As teorias de um philosopho são as resultantes do seu temperamento e da sua época. São o efeito intelectual da sua época sobre o seu temperamento. Outra cousa não podia ser.

Assim, pois, a filosofia de Friedrich Nietzsche é a resultante do seu temperamento e da sua época. O seu temperamento era de um asceta e de um louco. A sua época no seu país era de materialidade e de força. Resultou fatalmente uma teoria onde um ascetismo louco se casa com uma (involuntária que fosse) admiração pela força e pelo domínio. Resulta uma teoria onde se insiste na necessidade de um ascetismo e

ortografia original pessoana.

5 No livro de Nordau, existe um extenso capítulo sobre Nietzsche. Esse é um dado importante, porque, como revela Nuno Ribeiro, em alguns fragmentos do espólio pessoano sobre Nietzsche encontra-se a influência direta dessa leitura. 
Souza, C. F.

na definição d'esse ascetismo como um ascetismo de força e domínio. D'onde a assumpção de atitude christã da necessidade de dominar os seus instinctos, tornada aqui - mercê de contribuição fornecida pela loucura do autor - a necessidade de dominar toda a espécie de instinctos, incluindo os bons, torturando a própria alma, o próprio temperamento (noção delirante ${ }^{6}$ ).

Embora o livro Dégénérescence de Max Nordau não conste na biblioteca particular de Fernando Pessoa, há evidencias dessa leitura em listas e notas de leituras presentes no espólio pessoano ${ }^{7}$. $\mathrm{O}$ texto pessoano transcrito revela como o autor português estava influenciado pelo pensamento de Nordau, que em seu livro apresenta Nietzsche como um degenerado, próximo da loucura. Pessoa se interessou fortemente pela relação entre gênio e loucura, principalmente a partir de 1905, após o seu retorno a Lisboa ${ }^{8}$.

A relação entre Pessoa e Nietzsche não é aleatória, uma vez que Pessoa se interessou pela obra de Nietzsche. Existe já num primeiro momento um elo entre a literatura pessoana e a filosofia nietzschiana, como comprovam alguns documentos do espólio.

\section{II - Nietzsche e Alberto Caeiro: as palavras não são as coisas}

Aproximaremos agora as reflexões nietzschianas sobre a linguagem, presentes no texto Sobre verdade e mentira no sentido extramoral, da filosofia/poesia de Alberto Caeiro.

O texto nietzschiano em questão, escrito em 1873, é fulcral ${ }^{9}$ para análise da reflexão nietzschiana sobre a linguagem. Nietzsche

6 RIBEIRO, 2011, 112.

7 Op. cit., p.54.

8 Pessoa morou com sua mãe, seu padrasto e seus irmãos em Durban, na África do Sul, nos anos 1896-1905. O interesse do autor português pela relação entre genialidade e loucura se concentra sobretudo nos anos de 1905-1914.

9 Adotamos aqui a mesma metodologia utilizada por André Itaparica em seu artigo, Nietzsche: 
mostra, ao longo do texto, que existe um abismo entre as palavras e as coisas. Segundo o filósofo alemão as palavras são metáforas da realidade, não existe uma verdade oculta na linguagem: "Acreditamos saber algo das coisas mesmas, se falamos de árvores, cores, neve e flores, e no entanto não possuímos nada mais do que metáforas das coisas, que de nenhum modo correspondem às entidades de origem." (WL/VM, 1, KSA 1.875 ${ }^{10}$ ). A linguagem serviria para comunicar, expressar impressões, afetos. E há uma relação estreita entre linguagem e retórica, a retórica seria a essência da linguagem ${ }^{11}$. Uma linguagem eficaz seria aquela com alto teor de persuasão $^{12}$. Em sua crítica a respeito da linguagem Nietzsche vai dissociando a relação entre linguagem e verdade:

O que é a verdade, portanto? Um batalhão móvel de metáforas, metonímias, antropomorfismos, enfim, uma soma de relações humanas, que foram enfatizadas poética e retoricamente, transpostas, enfeitadas, e que após longo uso, parecem a um povo sólidas, canônicas e obrigatórias: as verdades são ilusões, das quais se esqueceu que o são, metáforas que se tornaram gastas e das quais se esqueceu que o são, metáforas que se tornaram gastas e sem força sensível, moedas que perderam sua efígie e agora só entram em consideração como metal, não mais como moedas. (WL/VM 1, KSA 1.875, tradução de RRTF)

crítica à metafísica como crítica à linguagem (ITAPARICA, 2014). Nesse texto, o pesquisador divide a obra de Nietzsche em três períodos e mostra que apesar do filósofo alemão ter modificado sua análise sobre a metafísica durante as três fases de seus escritos, Nietzsche mantém ao longo dos seus textos sua crítica em relação aos poderes representativos da linguagem.

10 Utilizamos para efeitos de citação do texto "Sobre a verdade e mentira no sentido extramoral" a tradução de Rubens Rodrigues Torres Filho, doravante citada como RRTF.

11 É importante ressaltar que essa relação entre linguagem e retórica é trabalhada no livro Verdade e linguagem em Nietzsche, organizado por Márcio Lima e André Itaparica (LIMA; ITAPARICA, 2014).

12 No artigo Nietzsche, acerca da persuasão wagneriana, Emmanuel Salanski explora a relação entre retórica e drama musical wagneriano, mostrando que a admiração que Nietzsche nutria nos primeiros tempos pela arte de Wagner não se corrompeu nem nos últimos escritos, como em $O$ Caso Wagner, em que Nietzsche ainda considera Wagner como um grande sedutor. (SALANSKI, 2014, p. 59-74). 
Souza, C. F.

A verdade, segundo o pensamento exposto nesse texto, tem relação direta com a ilusão. A linguagem seria construída a partir de imagens, metáforas e a partir do seu uso, a construção destas imagens vai se apagando e, com esse efeito, a palavra seria então erroneamente vista como portadora da verdade. É interessante ressaltar, que esse texto pertence ao jovem Nietzsche, que estava influenciado por Schopenhauer, próximo de questões ligadas à metafísica, como comprova seu livro $O$ Nascimento da Tragédia. Mas percebemos, ainda nesta primeira fase dos escritos nietzschianos, uma linha divisória entre o que se pode ou não conhecer e a impossibilidade de acesso à realidade metafísica. Já neste texto escrito em 1873, Nietzsche deixa claro que a verdade é apenas uma ilusão, e que a linguagem possui um caráter arbitrário e profundamente humano. São esses os aspectos que pretendemos trabalhar na escrita de Alberto Caeiro e em toda a estrutura criada por Pessoa para assegurar a filosofia pagã deste heterônimo pessoano.

Alberto Caeiro começa a ser elaborado por Pessoa no ano de 1912, segundo o depoimento expresso em carta enviada pelo autor português a Adolfo Casais Monteiro:

Aí por 1912, salvo erro (que nunca pode ser grande), veio-me à ideia escrever uns poemas de índole pagã. Esbocei umas coisas em verso irregular (não no estilo Álvaro de Campos, mas num estilo de meia regularidade), e abandonei o caso. Esboçara-se-me, contudo, numa penumbra mal urdida, um vago retrato da pessoa que estava a fazer aquilo. (Tinha nascido, sem que eu soubesse, o Ricardo Reis).

Ano e meio, ou dois anos depois, lembrei-me um dia de fazer uma partida ao Sá-Carneiro - de inventar um poeta bucólico, de espécie complicada, e apresentar-lho, já me não lembro como, em qualquer espécie de realidade. Levei uns dias a elaborar o poeta mas nada consegui. Num dia em que finalmente desistira - foi em 8 de Março de 1914 - acerquei-me de uma cómoda alta, e, tomando um papel, comecei a escrever, de pé, como escrevo sempre que posso. E escrevi trinta e tantos poemas a fio, numa espécie de êxtase cuja natureza não conseguirei

250 I Cad. Nietzsche, São Paulo, v.36 n.1, p. 245-265, 2015. 
definir. Foi o dia triunfal da minha vida, e nunca poderei ter outro assim. Abri com um título, O Guardador de Rebanhos. E o que se seguiu foi o aparecimento de alguém em mim, a quem dei desde logo o nome de Alberto Caeiro. Desculpe-me o absurdo da frase: aparecera em mim o meu mestre. Foi essa a sensação imediata que tive. E tanto assim que, escritos que foram esses trinta e tantos poemas, imediatamente peguei noutro papel e escrevi, a fio, também, os seis poemas que constituem a Chuva Oblíqua, de Fernando Pessoa. Imediatamente e totalmente... Foi o regresso de Fernando Pessoa Alberto Caeiro a Fernando Pessoa ele só. Ou, melhor, foi a reacção de Fernando Pessoa contra a sua inexistência como Alberto Caeiro.

Aparecido Alberto Caeiro, tratei logo de lhe descobrir - instintiva e subconscientemente - uns discípulos. Arranquei do seu falso paganismo o Ricardo Reis latente, descobri-lhe o nome, e ajustei-o a si mesmo, porque nessa altura já o via. E, de repente, e em derivação oposta à de Ricardo Reis, surgiu-me impetuosamente um novo indivíduo. Num jacto, e à máquina de escrever, sem interrupção nem emenda, surgiu a Ode Triunfal de Álvaro de Campos - a Ode com esse nome e o homem com o nome que tem ${ }^{13}$.

Essa carta foi escrita vinte e um anos após o aparecimento dos heterônimos pessoanos (respeitando aqui em relação às datas toda a ficção que Pessoa cria em torno do tempo ${ }^{14}$ ). Esse fato mostra que depois de todo esse tempo de convívio com a obra de seus heterônimos, Fernando Pessoa possui um distanciamento de sua obra que o permite organizá-la de certa maneira. E que, na organização que o poeta português faz da sua despersonalização, coloca Alberto Caeiro no centro dos seus escritos. Caeiro, como podemos averiguar no trecho da carta aqui transcrita, é o mestre de Reis e de Campos.

13 PESSOA, 1986a, 199.

14 Em O manuscrito de O Guardador de Rebanhos de Alberto Caeiro, Ivo Castro mostra, através da análise minuciosa dos manuscritos de $O$ Guardador de Rebanhos, toda a ficção que envolve o dia triunfal de Fernando Pessoa (PESSOA, 1986b) 
Souza, C. F.

Mas, a importância de Caeiro não se esgota nesse dado, ele também foi mestre de Fernando Pessoa, como afirma o autor português no texto acima citado. Fortalecendo ainda mais a figura de Caeiro, Pessoa coloca ao seu dispor um outro eu, António Mora, que segundo nossa metodologia ${ }^{15}$ não chega a constituir um heterônimo pessoano, mas uma personalidade, que escreve em prosa e que terá papel importante na dinâmica da dramatização pessoana, porque seus escritos revelariam a filosofia pagã de Alberto Caeiro.

A poesia de Alberto Caeiro encontra-se intimamente relacionada com a natureza. Caeiro é poeta dos sentidos, entra em contato com o mundo supostamente pela visão e não pelo pensamento. A sua poesia apresenta um projeto pedagógico, cujo núcleo temático seria uma aprendizagem do desaprender, como consta no poema XXIV de $O$ Guardador de Rebanhos:

O que nós vemos das cousas são as cousas.

Porque veríamos nós uma cousa se houvesse outra?

Porque é que ver e ouvir seriam iludirmos

Se ver e ouvir são ver e ouvir?

O essencial é saber ver,

Saber ver sem estar a pensar,

Saber ver quando se vê

E nem pensar quando se vê

Nem ver quando se pensa.

Mas isso (tristes de nós que trazemos a alma vestida!),

Isso exige um estudo profundo,

Uma aprendizagem do desaprender ${ }^{16}$

15 Respeitando os escritos deixados por Pessoa, utilizamos a designação de heterônimos para Alberto Caeiro, Álvaro de Campos e Ricardo Reis, como o próprio criador português determinou. Os outros eus pessoanos, como António Mora são designados em nossa pesquisa como personalidades literárias. 16 Grifo nosso. 
E uma sequestração na liberdade daquele convento

De que os poetas dizem que as estrelas são as freiras eternas

$\mathrm{E}$ as flores as penitentes convictas de um só dia,

Mas onde afinal as estrelas não são senão estrelas

Nem as flores senão flores,

Sendo por isso que lhe chamamos estrelas e flores ${ }^{17}$.

Nesse poema encontramos os principais temas presentes na poesia de $O$ Guardador de Rebanhos: o apelo à visão, uma tentativa de desconstruir o mundo filtrado pelo pensamento, um contato próximo entre o homem e a natureza. Num primeiro momento, podemos aproximar a poesia de Caeiro da filosofia nietzschiana, isso porque ambas propõem essa aprendizagem do desaprender. Nietzsche, em sua crítica à linguagem, revela os aspectos estruturais da mesma, convidando o seu leitor a desaprender: desaprender o suposto caráter de verdade que estaria ligado às palavras, desaprender a relação supostamente íntima entre as palavras e as coisas, desaprender que existe um caminho direto entre o mundo e a realidade metafísica. Caeiro em sua poesia enfatiza também o caráter animal que possuímos (como Nietzsche o faz em seu texto sobre verdade e mentira): "Procuro despir-me do que aprendi/Procuro esquecer-me do modo de lembrar que me ensinaram,/e raspar a tinta com que me pintaram os sentidos/Desencaixotar as minhas emoções verdadeiras/desembrulhar-me e ser eu, não Alberto Caeiro,/ Mas um animal humano que a Natureza produziu ${ }^{18 \%}$. A proposta do poema é nítida (como um girassol ${ }^{19}$ ), o eu lírico pretende se limpar

17 PESSOA, 2008, 49.

18 Op. cit., 72.

19 Fazemos referência aqui ao início do poema II de $O$ Guardador de Rebanhos: O meu olhar é nítido como um girassol./Tenho o costume de andar pelas estradas/Olhando para a direita e para a esquerda,/E de vez em quando olhando para trás.../E o que vejo a cada momento/É aquilo que nunca antes tinha visto,/E eu sei dar por isso muito bem.../Sei ter o pasmo comigo/ Que tem uma criança ao nascer,/Reparasse que nascera deveras.../Sinto-me nascido a cada momento/Para a eterna novidade do mundo. (PESSOA, 2008, 19). 
Souza, C. F.

da civilização, que pintou os seus sentidos, deixar aparecer as suas verdadeiras emoções e o seu verdadeiro eu, que não tem nome, é um animal produzido pela natureza. Em Sobre verdade e mentira no sentido extramoral, Nietzsche também questiona a civilização e o intelecto humano, que seria o nosso diferencial da Natureza, ou a nossa Natureza diferencial: "Não há nada tão desprezível e mesquinho na natureza que, com um pequeno sopro daquela força do conhecimento, não transbordasse logo como um odre; e como todo transportador de carga quer ter seu admirador, mesmo o mais orgulhoso dos homens, o filósofo, pensa ver por todos os lados os olhos do universo telescopicamente em mira sobre seu agir e seu pensar" (WL/VM 1, KSA 1.875, tradução de RRTF). Através de uma determinada perspectiva poderíamos dizer que Caeiro cumpre a proposta nietzschiana aqui esboçada: se desvencilha da força do conhecimento, se aproxima da natureza, desvaloriza o pensar e o agir e potencializa suas emoções diante do mundo, da existência, esquecendo o possível mistério, o lado oculto das coisas:

O mistério das cousas, onde está ele?

Onde está ele que não aparece

Pelo menos a mostra-nos que é o mistério?

Que sabe o rio disso e que sabe a árvore?

$\mathrm{E}$ eu, que não sou mais do que eles, que sei disso?

Sempre que olho para as cousas e penso no que os homens pensam delas,

Rio como um regato que soa fresco numa pedra.

Porque o único sentido oculto das cousas

É elas não terem sentido oculto nenhum.

É mais estranho do que todas as estranhezas

$\mathrm{E}$ do que os sonhos de todos os poetas

E os pensamentos de todos os filósofos,

Que as cousas sejam realmente o que parecem ser

E não haja nada que compreender. 
Sim, eis o que os meus sentidos aprenderam sozinhos: -

As cousas não têm significação: têm existência.

As cousas são o único sentido oculto das cousas ${ }^{20}$.

O tema principal deste poema é a desconstrução do mistério das coisas, o eu lírico pretende devolver ao mundo a verdade que lhe é própria, uma existência pura, filtrada apenas pelos sentidos e não pelo suposto significado que cada coisa possui a partir da linguagem. Se por um lado a poesia de Caeiro pretende despir o homem de seus pensamentos, das imagens já viciadas pela nossa civilização ocidental, por outro lado a elaboração dessa poesia pressupõe todo um trabalho com a linguagem, e possui um caráter altamente reflexivo - como neste poema, o eu lírico parte de uma pergunta, de uma questão, $O$ mistério das cousas, onde está ele?, e todo o restante do poema é a tentativa de responder a essa questão, chegando à conclusão de que o sentido das coisas é a sua materialidade, para além do que vemos nada podemos afirmar, As cousas são o único sentido oculto das cousas. A partir dessa reflexão sobre a poesia de Caeiro, nota-se uma problemática que compõe a sua estrutura literária. Toda a crítica de Caeiro sobre o pensar está pautada sobre a linguagem, surge a partir do desdobramento deste eu pessoano a respeito da existência e das consequências que o pensar exerce sobre o homem. É interessante perceber que o seu fazer poético se constrói justamente sobre o pilar do pensamento. Sem pensamento não há linguagem, sem linguagem não há crítica. Todo o movimento reflexivo de Caeiro sobre a existência está pautado num pensamento, que só estabelece contato com a realidade via linguagem.

Existe uma clara diferença entre o pensamento de Nietzsche e de Caeiro. Nietzsche sabe dos limites da linguagem, não pretende instaurar uma nova e reveladora verdade; Caeiro parece desafiar a linguagem, questiona a civilização e a importância do pensar em

20 PESSOA, 2008, 65. 
Souza, C. F.

detrimento do sentir, mas acredita ainda numa verdade, acredita que é possível raspar a tinta com que nos pintaram os sentidos. Mas toda a sua filosofia está pautada não nos sentidos, mas na linguagem e numa suposta mensagem verdadeira que essa linguagem comportaria. Pessoa parece perceber essa falha na filosofia de Caeiro, esse hiato entre o núcleo pedagógico da sua poesia e a estrutura da linguagem, que como Nietzsche defende em Sobre verdade e mentira no sentido extramoral, as palavras não coincidem com as coisas, quando digo flores, estou dizendo não a flor, mas uma metáfora para uma coisa que chamamos de flor. $\mathrm{O}$ que nos faz pensar que Pessoa se preocupou com essa, digamos, falha da filosofia de Caeiro é o fato de o autor português ter colocado à disposição de Caeiro uma série de outros eus: afinal ele foi o mestre de Álvaro de Campos, de Ricardo Reis, do próprio Pessoa e de António Mora. Por que tantos textos dedicados à filosofia pagã de Alberto Caeiro? Por que enfatizar a importância pedagógica/filosófica da sua poesia? Campos com sua poesia irreverente, cheia de movimentos e com claras propostas de demolição do universo literário firmemente construído (como é o caso da Ode Triunfal), não tem outro eu pessoano que defenda suas palavras, que a endossem, dentro do espaço literário pessoano. Até ocorre o contrário, Campos entra em polêmica com o seu próprio criador $^{21}$. Reis, por outro lado, com sua poesia classicista, formal, límpida, também não possui seguidores dentro da literatura pessoana e até mostra que possui divergências com Álvaro de Campos ${ }^{22}$. Ou seja, a poesia e a filosofia de Caeiro mereceram um destaque muito especial dentro da criação literária de Pessoa.

21 Fazemos referência aqui ao texto publicado por Campos, na revista Athena $\mathrm{n}^{\circ} 2$ em novembro de 1924 (PESSOA, 2000, pp. 230-235), no qual o heterônimo pessoano questiona o seu criador, Fernando Pessoa, a partir de uma publicação que Pessoa havia feito na mesma revista e, nesta, esboçado suas reflexões acerca da filosofia/metafísica.

22 No seguinte fragmento do espólio assinado por Ricardo Reis, a divergência de opiniões sobre a poesia em Reis e Campos é evidente: "Diz Campos que a poesia é uma prosa em que o rythmo é artificial. Considera a poesia como uma prosa que envolve música, donde o artifício. Eu, porém, antes diria que a poesia é uma música que se faz com ideas, e por isso com palavras. Considerai que será o fazerdes música com ideas, em vez de com emoções. Com

256 | Cad. Nietzsche, São Paulo, v.36 n.1, p. 245-265, 2015. 
Em Notas para recordação do meu mestre Caeiro, Álvaro de Campos defende que:

O meu mestre Caeiro não era um pagão: era o paganismo. O Ricardo Reis é um pagão, o António Mora é um pagão, eu sou um pagão; o próprio Fernando Pessoa seria um pagão, se não fosse um novelo embrulhado para o lado de dentro. Mas o Ricardo Reis é um pagão por carácter, o António Mora é um pagão por inteligência, eu sou um pagão por revolta, isto é, por temperamento. Em Caeiro não havia explicação para o paganismo; havia consubstanciação ${ }^{23}$.

É interessante perceber que a filosofia de Caeiro, expressa supostamente em sua poesia, vai sendo estruturada a partir de textos como este. Campos reforça a sua posição de discípulo de Caeiro $O$ meu mestre Caeiro. Depois explora o paganismo de seu mestre, diferenciando-o dos outros eus pessoanos e até do paganismo do próprio Pessoa. Em Caeiro não haveria, segundo Campos, uma distância entre o eu e o paganismo, Caeiro seria a consubstanciação da filosofia pagã. Esse texto, como outros, faz parte, segundo nossa análise, de uma estratégia pessoana para fortalecer a figura e a filosofia de Caeiro.

Ricardo Reis redigiu um texto para servir de introdução à obra de Caeiro, na qual apresenta a filosofia pagã de seu mestre:

A obra de Caeiro representa a reconstrução integral do paganismo, na sua essência absoluta, tal como os gregos nem os romanos, que viveram nele e por isso o não pensaram, o puderam fazer. A obra, porém e o seu paganismo, não foram nem pensados nem até sentidos: foram vividos com o que quer que seja que é em nós mais profundo que o sentimento ou a razão.

emoções fareis só música. Com emoções que caminham para as ideas, que se agregam ideas para se definir, fareis o canto". [BNP/E3-21-115].

23 CAMPOS, 1997, 42. 
(...)

O Grande Pã renasceu ${ }^{24}$ !

Neste trecho além de ficar evidente a exaltação da filosofia pagã de Caeiro, existe um aspecto interessante e paradoxal: a diferença entre o paganismo de Caeiro e o paganismo dos gregos e dos romanos. Os gregos e os romanos encontravam-se imersos no paganismo, viveram dentro dele, então não pensaram sobre o paganismo. Mas justo Caeiro que era, segundo Reis neste mesmo escrito, ignorante da vida e quase ignorante das letras, quase sem convivio nem cultura ${ }^{25}$, ele um homem tão simples, foi capaz de reconstruir a essência absoluta do paganismo, foi para além dos gregos e dos romanos. Esses trechos da prosa de Reis deixam evidente todo o esforço pessoano em consolidar a filosofia pagã de Caeiro. Todo esse empenho pessoano no fortalecimento da filosofia pagã do Grande Pã que renasceu, se deve, segundo nossa perspectiva de análise, ao fato de Pessoa perceber que na poesia de Caeiro existe uma contradição, criada de forma intencional ou não pelo autor português, que pretende contornar essa lacuna através do discurso dos outros eus sobre Caeiro. A contradição da poesia de Caeiro, e aqui chamamos a atenção sobretudo para a obra $O$ Guardador de Rebanhos, é a construção de uma filosofia através de uma poesia que se estrutura a partir das limitações representativas da linguagem. Caeiro critica o poeta místico e o filósofo, como podemos averiguar no poema XXVIII de $O$ Guardador de Rebanhos: “Os poetas místicos são filósofos doentes,/E os filósofos são homens doidos ${ }^{26 "}$. Mas será que o mestre Caeiro não se encaixa nas duas categorias: poeta místico e filósofo? Será que Caeiro não sofre do impulso para formar metáforas a que Nietzsche se refere em seu texto aqui analisado:

24 PESSOA, 2008, 11.

25 Op. cit., 12.

26 Op. cit., 2008, p.73.

258 I Cad. Nietzsche, São Paulo, v.36 n.1, p. 245-265, 2015. 
(...) Esse impulso à formação de formação de metáforas, esse impulso fundamental do homem, que não se pode deixar de levar em conta nem por um instante, porque com isso o homem mesmo não seria levado em conta, quando se constrói para ele, a partir de suas criaturas liquefeitas, os conceitos, um novo mundo regular e rígido como uma praça forte, nem por isso, na verdade, ele é subjugado e mal é refreado. Ele procura um novo território para a sua atuação e um outro leito de rio, e o encontra no mito e, em geral, na arte. Constantemente ele embaralha as rubricas e compartimentos dos conceitos propondo novas transposições, metonímias, constantemente ele mostra o desejo de dar ao mundo de que dispõe o homem acordado uma forma tão cromática irregular, inconsequentemente incoerente, estimulante e eternamente nova como a do mundo do sonho. (WL/VM 1, KSA 1.875, tradução de RRTF)

Esse fragmento do texto nietzschiano parece se encaixar de forma confortável à escrita de Caeiro. Isto porque o mestre dos heterônimos e do próprio Pessoa não se limitou ao território da arte e do mito, foi além, sua arte pressupõe uma filosofia. E podemos afirmar esse fato porque o teor filosófico da poesia de Caeiro irá transbordar em números escritos deixados no espólio do autor português, alguns dos quais já evidenciados aqui.

Um outro eu pessoano que irá exercer um importante papel no diálogo entre Alberto Caeiro, Álvaro de Campos e Ricardo Reis é António Mora que, assim como Reis, Campos e Caeiro, fará parte da composição deste drama em gente ${ }^{27}$ pessoano, sendo influênciado por Alberto Caeiro, como podemos constatar no seguinte trecho:

27 Em Dezembro de 1928 no número 17 da revista Presença, foi publicada a tábua bibliográfica pessoana e nesse texto Pessoa afirma que a elaboração da obra dos seus heterônimos (Alberto Caeiro, Ricardo Reis e Álvaro de Campos) constituiu um drama em gente, em vez de um drama em actos, como atesta a seguinte passagem: "As obras destes três poetas formam, como se disse, um conjunto dramático; e está devidamente estudada a entreacção intelectual das personalidades, assim como as suas próprias relações pessoais. Tudo isto constará de biografias a fazer, acompanhadas, quando se publiquem, de horóscopos e, talvez, de fotografias. É um drama em gente, em vez de em actos. (Se estas três individualidades são mais ou menos reais que o próprio Fernando Pessoa - é problema metafísico, que este, ausente do segredo 
O Antonio Mora era uma sombra de veleidades especulativas. Passava a vida a mastigar Kant e tentar ver com o pensamento se a vida tinha sentido. Indeciso como todos os fortes, não tinha encontrado a verdade, ou o que para elle fosse verdade, o que para mim é o mesmo. Encontrou Caeiro e encontrou a verdade. O meu mestre Caeiro deu-lhe a alma que elle não tinha; poz dentro do Mora peripherico, que elle sempre tinha sido, um Mora central. E o resultado foi a reducção a systema e a verdade logica dos pensamentos instictivos de Caeiro. $\mathrm{O}$ resultado triumphal foi esses dois tratados, maravilhas de originalidade e de pensamento, O Regresso dos Deuses e os Prolegomenos a uma Reformação do Paganismo ${ }^{28}$.

Esse fragmento mostra a estreita relação entre Mora e Caeiro. Mora encontrou a verdade quando encontrou Alberto Caeiro, ganhou alma e o resultado deste encontro estaria nos dois tratados citados no trecho. É importante perceber que Mora possui um importante papel enquanto divulgador do paganismo de Caeiro, como defende Luís Filipe Teixeira, responsável pela edição crítica desta personalidade pessoana: “A função de Mora no sistema pessoano é a de se constituir como dimensão ou grau da realidade (intelectual do paganismo), e o mesmo é dizer, como alicerce teórico do neopaganismo português, enquanto dispositivo figurado dessa metafísica

dos Deuses, e ignorando portanto o que seja realidade, nunca poderá resolver".) PESSOA, 2000, p.404. Podemos assegurar a participação de António Mora neste drama em gente baseados na afirmação do próprio Pessoa no seguinte trecho que faria parte de uma obra intitulada Aspectos: "Esse Alberto Caeiro teve dois discípulos e um continuador philosophico. Os dois discípulos, Ricardo Reis e Alvaro de Campos, seguiram caminhos differentes; tendo o primeiro intensificado e tonardo orthodoxo, o paganismo descoberto por Caeiro, e o segundo baseando-se em outra parte da obra de Caeiro, desenvolvido por um systema inteiramente differente, e baseado inteiramente nas sensações. O continuador philosophico, Antonio Móra (os nomes são tão inevitáveis, tão impostos de fóra como as personalidades), tem um ou dois livros a escrever, onde provará completamente a verdade metaphysica e practica, do paganismo.(...)" [BNP/E3-20-70 a 72]

28 [BNP/E3-71/A-24 a 26] Como nas demais transcrições de documentos do espólio aqui realizadas, optamos por manter a ortografia original na transcrição deste documento. 
das sensações (que tem por lei sentir tudo de todas as maneiras ${ }^{29}$ ). Os inúmeros textos assinados por essa personalidade deixados no espólio pessoano tratam da questão do paganismo na poesia de Caeiro. E Mora também analisa o paganismo de Nietzsche, como veremos na próxima seção deste artigo.

III - António Mora: escritos sobre o paganismo de Nietzsche e de Caeiro

Pessoa estabelece um diálogo com o paganismo de Nietzsche através dos escritos da sua personalidade literária, António Mora. Mora vai criticar o helenismo de Nietzsche, como podemos averiguar no seguinte documento do espólio:

O helenismo budhista de Nietzsche (versus de Gaultier)

O grego, porém, podendo conceber a vida como passageira, não a concebia como illusoria. Essa idéa é ou hindu ou christan. $\mathrm{O}$ morto, para o pagão, é uma sombra; isto é, é uma cousa menos real que o vivo. Como se conciliará esse conceito com o da illusão da vida?

O illusorio só pode ser concebido como illusorio em virtude de uma oposição real ${ }^{30}$.

Trata-se de um importante texto, pois nele aparece a questão da ilusão e do real. Segundo Mora o ilusório pressupõe o real. E esse ponto é explorado em contraposição à vivência dos gregos, que, de acordo com essa personalidade pessoana, viviam a vida como passageira, não necessitavam da ilusão, a tragédia da existência humana era vivida com naturalidade pelos gregos. Segundo o documento, o helenismo de Nietzsche se aproxima do budismo, isto porque para o autor alemão a ilusão possui um caráter importante

29 PESSOA, 2002, 31.

30 [BNP/E3-12/A-8] 
Souza, C. F.

diante da vida, do real, assim como para o budismo, cuja proposta seria desapegar o sujeito das ilusões criadas pelo próprio eu, pelo ego e pela realidade. É interessante observar que a opinião de Mora sobre o paganismo de Nietzsche está de acordo com a opinião do próprio Pessoa que escreve, (transcrito na epígrafe deste artigo): "O paganismo de Nietzsche é um paganismo estrangeiro. Há erros constantes de pronúncia na sua interpretação do helenismo ${ }^{31}$." Tanto Pessoa quanto Mora parecem concordar que o paganismo de Nietzsche não traduz de fato o paganismo helênico, há erros na interpretação do paganismo nietzschiano. Além de António Mora e do próprio Fernando Pessoa, outro eu pessoano, Ricardo Reis, também refletiu e criticou o paganismo de Nietzsche:

Todos os movimentos que, adentro da nossa civilização, tem havido no sentido do paganismo, têm pecado pela sua origem cristã. Todos os pseudo-pagãos do nosso tempo não conseguiram uma alma pagã antes de projectarem o seu paganismo. É cristão o sentimento com que desejam o paganismo. Quando muito, pode dizer-se deles que têm uma ânsia cristã do paganismo. Em nenhum caso se pode deles dizer que têm um conceito justo do paganismo. Podem sentir altamente a beleza e a calma dos deuses; mas de que serve que o façam, se por pagã que seja, ou pretendam que seja, a sua inteligência - ou, quando muito, a sua imaginação -, a sua sensibilidade está secularmente cristianizada?

Estas considerações se aplicam a todos, sem excepção, quantos têm querido reconstruir o paganismo desde que ele morreu. Dirigem-se tanto ao esforço reconstrutor de um Matthew Arnold, como ao de um Oscar Wilde. Em Nietzsche, em que mais parecia que se devesse falar, é melhor que não falemos, tão repelentemente cristã se contorce aquela débil e doentia mentalidade ${ }^{32}$.

31 PESSOA, 1968, 135.

32 REIS, 2003, 94.

262 | Cad. Nietzsche, São Paulo, v.36 n.1, p. 245-265, 2015. 
Neste trecho percebemos que Reis sabia da importância do paganismo nietzschiano, mas o heterônimo pessoano relaciona o paganismo de Nietzsche ao cristianismo, tão combatido em diversos textos do autor alemão. Todas essas críticas dirigidas ao paganismo de Nietzsche deixam-nos crer que, realmente, a leitura pessoana da obra nietzschiana foi realizada de forma lateral, como demonstramos no início deste artigo. O livro de Max Nordau (Degenerescência), lido por Pessoa parece ter sido a mais importante referência do pensamento de Nietzsche para o autor português. Chama a atenção o impacto que a obra de Nietzsche teve na criação literária pessoana, sobretudo no que diz respeito à questão do paganismo. Mesmo tecendo duras críticas (e talvez até injustas) ao paganismo de Nietzsche, essa reflexão transbordou na obra de Fernando Pessoa. Utilizando sua própria assinatura e a de outros eus, como Mora e Reis, temos o registro da influência de Nietzsche no espaço literário de Pessoa, ainda que seja com alto teor crítico, o nome e o pensamento do autor alemão ficaram registrados. E não podemos esquecer a relação ainda que indireta entre Caeiro e Nietzsche, ambos engajados em desconstruir verdades, refletir sobre a existência e criticar a linguagem, cada qual em seu território - Caeiro na poesia e Nietzsche na filosofia, porém tanto um como outro quiseram transitar entre os limites do saber e da arte. Nietzsche, a nosso ver, foi um pouco além, pois colocou em xeque o poder representativo da linguagem e questionou a existência de uma conexão entre linguagem e verdade. Caeiro com sua poesia pagã ainda acreditava na designação das coisas, reafirmando um elo (para Nietzsche impossível) entre as palavras e as coisas.

\footnotetext{
Abstract: In this article we intend to establish the relation between the meditations about language presented by the philosopher Friedrich Nietzsche in his text On Truth and Lie in an Extra-Moral Sense and the pagan philosophy of Alberto Caeiro, an heteronym of Fernando Pessoa. We will use in the body of this analysis the text of Nietzsche already
} 
Souza, C. F.

referred, the work The Keeper of Sheep by Alberto Caeiro and some prose texts of Fernando Pessoa, António Mora, Ricardo Reis and Álvaro de Campos. This article is divided in three parts: in the first part, we'll show Pessoa's readings about the work of Nietzsche, in a second moment we'll elucidate the dynamic of language concerning the pagan philosophy of Alberto Caeiro and its possible relations with the criticism about language in the early work of young Nietzsche and in a third moment the relation between the paganism of Nietzsche and the one attributed to master Caeiro in the light of the writings of António Mora, Fernando Pessoa and Ricardo Reis.

Keywords: Nietzsche - language - Alberto Caeiro - Fernando Pessoa - paganism

\section{referências bibliográficas}

CAMPOS, Álvaro. Notas para a recordação do meu mestre Caeiro. Lisboa: Editoral Estampa, 1997.

ITAPARICA, André. "Nietzsche: crítica à metafísica como crítica à linguagem". In: LIMA, Márcio José Silveira, ITAPARICA, André Luís Mota (Organizadores). Verdade e Linguagem em Nietzsche. Salvador: Edufba, 2014, p. 105-119.

LIMA, Márcio José Silveira, ITAPARICA, André Luís Mota (Organizadores). Verdade e Linguagem em Nietzsche. Salvador: Edufba, 2014.

MATTIA, Riccardi. Dionysus or Apollo? The Heteronym António Mora as Moment of Nietzsche’s Reception by Pessoa. Portuguese Studies. v.23, n01, 2007. pp 109-123.

NIETZSCHE, Friedrich. Obras incompletas. Tradução e notas de Rubens Rodrigues

Torres Filho. Seleção e ensaio de Gérard Lebrun. São Paulo: Editora 34, 2014. . O caso Wagner: um problema para músicos. Tradução de Paulo de César Souza.

São Paulo: Companhia das Letras, 1999.

. Sämtliche Werke. Kritische Studienausgabe [KSA]. Berlim: Walter de Gruyter, 1988, v.1.

. Sämtliche Werke. Kritische Studienausgabe [KSA]. Berlim: Walter de Gruyter, 1988, v.3.

. Sämtliche Werke. Kritische Studienausgabe [KSA]. Berlim: Walter de Gruyter, 1988, v.7.

PESSOA, Fernando. Obras de António Mora. Edição crítica de Fernando Pessoa. Vol VI. Lisboa: INCM, 2002.

264 | Cad. Nietzsche, São Paulo, v.36 n.1, p. 245-265, 2015. 
. Crítica - ensaios, artigos e entrevistas. Edição de Fernando Cabral Martins. Lisboa: Assírio \& Alvim, 2000.

. Escritos intimos, Cartas e Páginas Autobiográficas. Introdução, organização e notas de António Quadros. Lisboa: Europa-América, 1986a.

. Escritos filosóficos. Edição de António Pina Coelho.Volume I. Lisboa: Ática, 1968.

. O manuscrito de O Guardador de Rebanhos de Alberto Caeiro. Apresentação, textos e notas de Ivo Castro. Lisboa: Dom Quixote, 1986b.

. Poesia completa de Alberto Caeiro. Edição de Fernando Cabral Martins e Richard Zenith. $5^{\circ}$ ed. São Paulo: Companhia de Bolso, 2008.

REIS, Ricardo. Prosa. Edição de Manuela Parreira da Silva. Lisboa: Assírio \& Alvim, 2003.

RIBEIRO, Nuno. Fernando Pessoa e Nietzsche: o pensamento da pluralidade. Lisboa: Verbo, 2011.

SALANSKI, E. "Nietzsche, acerca da persuasão wagneriana”. In: LIMA, Márcio José Silveira, ITAPARICA, André Luís Mota (Organizadores). Verdade e Linguagem em Nietzsche. Salvador: Edufba, 2014, p. 59-74.

Artigo recebido para publicação em 18/06/2014.

Artigo aceito para publicação em 21/11/2014. 
